\title{
Association between knowledge and adherence to foot self-care practices performed by diabetics
}

\author{
Associação entre conhecimento e adesão às práticas de autocuidado com os pés realizadas por diabéticos \\ Asociación entre conocimiento y adherencia a las prácticas de autocuidado con los pies realizadas por diabéticos
}

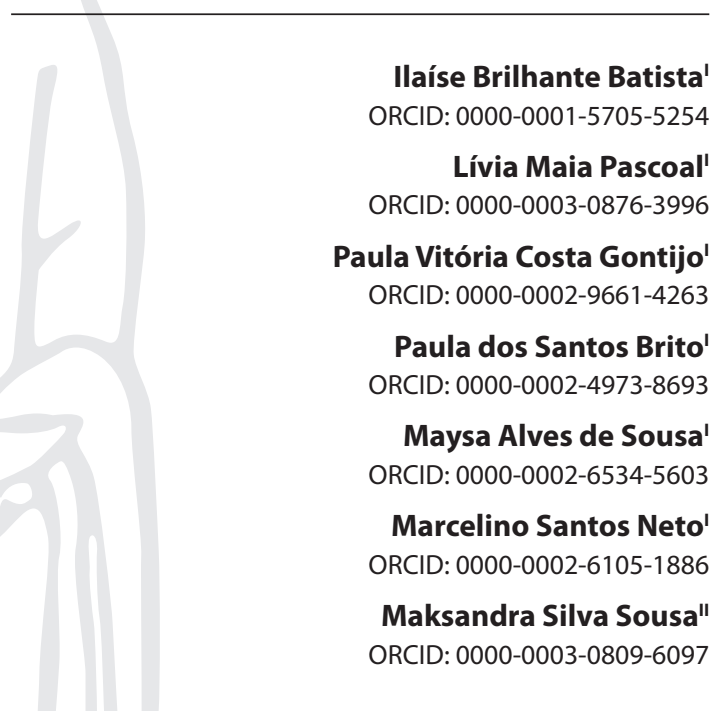

'Universidade Federal do Maranhão. Imperatriz, Maranhão, Brazil. "Secretaria Municipal de Saúde do Maranhão. Imperatriz, Maranhão, Brazil.

How to cite this article: Batista IB, Pascoal LM, Gontijo PVC, Brito PS, Sousa MA, Santos Neto M, et al. Association between knowledge and adherence to foot self-care practices performed by diabetics. Rev Bras Enferm. 2020; 73(5):e20190430. doi: http://dx.doi.org/10.1590/0034-7167-2019-0430

Corresponding author:

Paula Vitória Costa Gontijo

E-mail: paulagontijo17@hotmail.com

EDITOR IN CHIEF: Antonio José de Almeida Filho ASSOCIATE EDITOR: Alexandre Balsanelli

\section{ABSTRACT}

Objectives: to verify the association between knowledge and adherence to foot self-care practices performed by patients with diabetes mellitus type 2 . Methods: cross-sectional, descriptive study carried out with 197 patients in basic health units located in the Northeast region of Brazil. For data collection, we used a semi-structured questionnaire that addressed issues inherent to knowledge and Diabetes Self-Care Activities. Results: we observed that patients with moderate knowledge about self-care practices were more likely to perform foot self-examination, dry the interdigital spaces, moisturize their feet with creams and oils, observe the presence of mycosis and ingrown toenail when compared to patients with insufficient knowledge. Conclusions: the patients' level of knowledge was closely related to the self-care activities carried out, which reinforces the importance of nurses working on training those on essential health care.

Descriptors: Diabetes Mellitus; Knowledge; Self-Care; Foot; Nursing.

\section{RESUMO}

Objetivos: verificar a associação entre o conhecimento e a adesão às práticas de autocuidado com os pés realizadas por pacientes com diabetes mellitus tipo 2. Métodos: estudo transversal, descritivo, realizado com 197 pacientes em unidades básicas de saúde localizadas na região Nordeste do Brasil. Para a coleta de dados, foi utilizado um questionário semiestruturado que abordava questões inerentes ao conhecimento e às Atividades de Autocuidado com o Diabetes. Resultados: observou-se que os pacientes com conhecimento moderado sobre as práticas de autocuidado tiveram mais chances de realizar autoexame dos pés, secar os espaços interdigitais, hidratar os pés com cremes e óleos, observar a presença de micose e unha encravada, quando comparados aos pacientes com conhecimento insuficiente. Conclusões: o nível de conhecimento dos pacientes apresentou estreita relação com as atividades de autocuidado realizadas, o que reforça a importância de o enfermeiro atuar na capacitação daqueles sobre os cuidados essenciais com sua saúde.

Descritores: Diabetes Mellitus; Conhecimento; Autocuidado; Pé; Enfermagem.

\section{RESUMEN}

Objetivos: verificar la asociación entre conocimiento y adherencia a las prácticas de autocuidado de pacientes con diabetes mellitus tipo 2. Métodos: estudio descriptivo, transversal, realizado con 197 pacientes en unidades básicas de salud ubicadas en el Noreste de Brasil. Para la recopilación de datos, fue utilizado un cuestionario semiestructurado que aborda temas relacionados con el conocimiento y las actividades de autocuidado, como la diabetes. Resultados: ha observado que los pacientes con control moderado sobre las prácticas de autocuidado han tenido más probabilidades de realizar autoexamen de los pies, secar los espacios interdigitales, hidratar los pies con cremas y aceites, observar la presencia de micras y uña encarnada, en comparación a los pacientes con conocimiento insuficiente. Conclusiones: el nivel de conocimiento de los pacientes estaba estrechamente relacionado con las actividades de autocuidado realizadas, lo que refuerza la importancia del enfermero actuar en la capacitación de aquellos acerca de los cuidados esenciales con su salud.

Descriptores: Diabetes Mellitus; Conocimiento; Autocuidado; Pie; Enfermería. 


\section{INTRODUCTION}

Diabetes mellitus (DM) stands out as one of the most prevalent chronic non-communicable diseases in the world, remaining a challenge for public health as it presents high morbidity and mortality caused by complications that interfere in the quality of life of patients ${ }^{(1)}$. One of the main complications is the diabetic foot, which results from pathophysiological processes such as infection and the appearance of ulcers with extensive tissue destruction ${ }^{(2)}$.

To prevent diabetic foot and other complications, the person affected with the disease needs continuous changes in lifestyle, such as healthy eating, using medications correctly, controlling blood glucose, exercising, and taking care of the feet ${ }^{(1)}$. However, for these changes to be achieved, it is essential to consider the social context of the individual, as this allows the identification of risk situations that may result in health needs of populations in situations of vulnerability, such as the level of knowledge, public policies, and family support network. Given the lack of resources for health services, such parameters contribute to face health challenges and guarantee the rights of the individual, family, and community ${ }^{(3)}$.

The monitoring of the therapeutic plan combined with the educational intervention for self-care is one of the most suitable strategies for the prevention of diabetes complications. Studies claim that activities involving assistance and teaching self-care, developed by nurses in primary care, contribute to disease control, and reduce the prevalence of foot ulcers and amputations $s^{(4-5)}$.

Nursing, with its workforce mainly in Single Health System (SUS), has the potential to continue and advance in the training of the individual, aiming at improving self-care and therapeutic monitoring of people with diabetes. Therefore, it is necessary to incorporate knowledge about health vulnerabilities and the challenges encountered in the practice of care that limit the performance of these professionals $s^{(3)}$. It is known that the effective performance of the nursing team leads the patient towards responsible and autonomous performance for self-care; therefore, health education actions are indispensable instruments for the successful implementation of the therapeutic plan and the orientation of preventive care or detection of risk situations that may interfere with the occurrence of foot injuries in people with diabetes ${ }^{(6)}$.

However, for these educational activities to be productive, patients' feet must be routinely evaluated during nursing consultations, to monitor the possibilities of changes, and to train the patients so that they can learn to detect risk factors early and know how to implement preventive measures. Within this perspective, from the evaluation during the patients' consultation, sufficient knowledge about the risk factors for the occurrence of diabetic foot should be provided, such as the correct nails cutting, the use of appropriate shoes, the self-examination of the patients'feet, among others, so that the patients can achieve effective self-care ${ }^{(7)}$.

In general, the approach to the foot of the person with DM is still a challenge for health professionals, since, in most cases, this assessment is being carried out inappropriately, either by the ineffective practice of a thorough physical examination or by the absence of materials or therapeutic education for professionals and patients ${ }^{(8)}$. Insufficient knowledge about proper foot management can also be related to the lack of adequate communication between the nurse and the patient ${ }^{(9)}$.
The practices of educational actions that guide the performance of nursing need to be articulated to the patients' demands, sharing knowledge and practice for an effective performance directed by nursing professionals as facilitators to strengthen the skills for self-care ${ }^{(10)}$. Studies have shown that diabetic people with low education have a lower level of knowledge about the care they should perform to their feet since the level of education interferes with understanding and adherence to these practices ${ }^{(11-12)}$. Although these studies have highlighted the relationship between sociodemographic variables and foot self-care, we have not identified any research that would associate levels of knowledge with the performance of self-care practices.

\section{OBJECTIVES}

To verify the association between knowledge and adherence to foot self-care practices performed by patients with diabetes mellitus type 2.

\section{METHODS}

\section{Ethical aspects}

The Ethics and Research Committee of the Universidade Federal do Maranhão (Federal University of Maranhão) approved this study. Data collection started after the approval of the Ethics Committee and the consent of the participants by signing the Informed Consent Form (ICF).

\section{Study Design, location, and period}

A cross-sectional, descriptive study, with a quantitative approach, carried out in three basic health units located in the Northeast region of Brazil. Data were collected from January to April 2019. The STROBE tool guided the steps of this methodology.

\section{Population: inclusion and exclusion criteria}

The population consisted of 197 patients who met the following inclusion criteria: being 18 years old or older, having a medical diagnosis of diabetes mellitus type 2 , and being followed up in one of the three units in which the study was developed. As an exclusion criterion, we established: not to have cognitive conditions to answer the proposed questions.

\section{Study Protocol}

Data collection was carried out by undergraduate Nursing and Medicine students who are part of a study group that develops activities in primary care with patients with diabetes mellitus type 2. In order to avoid bias during the collection, the primary researcher carried out training, with four hours of duration, so that the propaedeutic methods inherent to the interview were reviewed and standardized.

The data were obtained with the aid of an instrument constructed from the literature relevant to the subject ${ }^{(13-14)}$. The questions referred to socioeconomic variables, such as sex, age, schooling (years of education), work situation, income, housing 
situation, and variables related to patients' adherence and knowledge about foot self-care practices.

We assessed the level of knowledge by applying ten questions aimed at patients' knowledge about the care that a person with diabetes should have with their feet ${ }^{(13)}$. Each question evaluated corresponded to 1 point, and the sum of the individual scores totaled 10 points. The answers obtained were classified into low or insufficient knowledge (percentage of correct answers below $50 \%$ ), moderate knowledge (percentage of correct answers between $50 \%$ and $80 \%$ ), and good knowledge (percentage of correct answers above $80 \%)^{(11)}$. In turn, to assess patients' behavior regarding adherence to self-care practices, the Diabetes Self-Care Activities Questionnaire (DSQ) was applied, a version translated and adapted to the Brazilian culture of the Summary of Diabetes Self-Care Activities (SDSCA), which is parameterized on days of the week, on a scale of 0 to 7 , equivalent to the behaviors related to the last seven days ${ }^{(12)}$. Then, the response provided by the patients was used to classify their adherence to the practice of self-care as positive when they reported performing the activity for at least five days ${ }^{(15)}$.

\section{Results analysis and statistics}

The data obtained were tabulated and stored in a database in the Office Excel 2010 software. The SPSS program (version 24.0) for MAC OS supported the statistical analysis. In the univariate descriptive analysis, absolute and percentage frequency measures were used. No patient was classified as having good knowledge, so all statistical analyses were performed, taking into account only the classifications with low or moderate knowledge.

The Mann Whitney test was used to compare groups according to knowledge (categorical variable) and the number of days (numerical variable) on which the patients performed the self-care activity. Then, the number of days on which the activities were carried out was categorized, and the sample we divided into two groups: patients who adhered to self-care practices ( $\geq 5$ days) and those who did not adhere ( $<5$ days). This categorization was performed to assess the association between socioeconomic data and knowledge about the practice of self-care with adherence to foot care. For that, the chi-square or Fisher's exact tests were applied. The odds ratio (OR) was estimated as a measure of association, and their respective $95 \%$ confidence intervals $(95 \% \mathrm{Cl})$. The statistical significance adopted was $5 \%$ ( $p<0.05)$.

\section{RESULTS}

In the present study, 197 patients with type 2 DM were evaluated, and the results obtained showed that most of the participants were female $(n=129 ; 65.5 \%)$, aged over 60 years $(n=125$; $63.8 \%)$, married $(n=100 ; 50.8 \%)$, inactive $(n=140 ; 74.1 \%)$, with income less than or equal to a minimum wage ( $n=164 ; 90.6 \%)$, who did not live alone $(n=169 ; 86.7 \%)$ and had an education of up to 4 years of study ( $n=96 ; 52.5 \%$ ). Regarding the level of knowledge of the investigated patients, it was possible to observe that most of the sample had low knowledge ( $n=167 ; 84.8 \%$ ). When analyzing the association between the sociodemographic variables and the level of knowledge, a statistical association was identified only for the variable "gender," indicating that male patients had a lower level of knowledge than women $(p=0.008)$. Table 1 shows these data.

Table 1 - Association between sociodemographic variables and the classification of knowledge about the practice of self-care in patients with diabetes mellitus type 2, Imperatriz, Maranhão, Brazil, 2019

\begin{tabular}{|c|c|c|c|c|}
\hline \multirow[b]{2}{*}{ Variables } & \multicolumn{2}{|c|}{ Knowledge } & \multirow[b]{2}{*}{$\begin{array}{l}\text { Total } \\
\text { n (\%) }\end{array}$} & \multirow[b]{2}{*}{$\stackrel{p}{p}$} \\
\hline & $\begin{array}{l}\text { Low } \\
\text { n(\%) }\end{array}$ & $\begin{array}{c}\text { Moderate } \\
\text { n(\%) }\end{array}$ & & \\
\hline \multicolumn{5}{|l|}{ Gender } \\
\hline Female & $103(79.8)$ & $26(20.2)$ & $129(65.5)$ & 0.008 \\
\hline Male & $64(94.1)$ & $4(5.9)$ & $68(34.5)$ & \\
\hline \multicolumn{5}{|l|}{ Age } \\
\hline$\leq 60$ years & $61(85.9)$ & $10(14.1)$ & $71(36.2)$ & 0.720 \\
\hline$>60$ years & $105(84.0)$ & $20(16.0)$ & $125(63.8)$ & \\
\hline \multicolumn{5}{|l|}{ Schooling (years of study) } \\
\hline $0-4$ & $84(87.5)$ & $12(12.5)$ & $96(52.5)$ & 0.426 \\
\hline $5-8$ & $37(86.0)$ & $6(14.0)$ & $43(23.6)$ & \\
\hline $9-12$ & $23(79.3)$ & $6(20.7)$ & $29(15.7)$ & \\
\hline 13 or more & $11(73.3)$ & $4(26.7)$ & $15(8.2)$ & \\
\hline \multicolumn{5}{|l|}{ Marital Status } \\
\hline Married & $85(85.0)$ & $15(15.0)$ & $100(50.8)$ & 0.836 \\
\hline Widow/widower & $46(82.1)$ & $10(17.9)$ & $56(28.4)$ & \\
\hline Separated/divorced & $19(90.5)$ & $2(9.5)$ & $21(10.7)$ & \\
\hline Single & $14(82.4)$ & $3(17.6)$ & $17(8.6)$ & \\
\hline Civil Union & $3(100)$ & $0(0.0)$ & $3(1.5)$ & \\
\hline \multicolumn{5}{|l|}{ Work situation } \\
\hline Inactive & $121(86.4)$ & $19(13.6)$ & $140(74.1)$ & 0.253 \\
\hline Active & 39 (79.6) & $10(20.4)$ & 49 (25.9) & \\
\hline \multicolumn{5}{|l|}{ Income } \\
\hline$\leq 1$ minimum wage & $142(86.6)$ & $22(13.4)$ & $164(90.6)$ & 0.426 \\
\hline \&gt; 1 minimum wage & $14(82.4)$ & $3(17.6)$ & $17(9.4)$ & \\
\hline \multicolumn{5}{|l|}{ Housing situation } \\
\hline Lives alone & $25(96.2)$ & $1(3.8)$ & $26(13.3)$ & 0.061 \\
\hline Do not live alone & $140(82.8)$ & $29(17.2)$ & $169(86.7)$ & \\
\hline General knowledge & $167(84.8)$ & $30(15.2)$ & $197(100.0)$ & \\
\hline
\end{tabular}

Note: *Chi-square Test.

Table 2 shows the relationship between the level of knowledge about foot care and the performance of daily care. This result showed that patients with a moderate level of knowledge had a greater tendency to perform foot self-care practices for more days during the week than patients with low knowledge. The variables that showed a statistical association were: in how many of the past seven days did you self-examined your feet $(p<0.001)$; in how many of the past seven days did you dry the spaces between your toes after washing them ( $p<0.001$ ); in how many of the past seven days did you moisturize your feet with creams and oils ( $p=0.024)$; in how many of the past seven days did you observe the presence of interdigital mycosis ( $p=<0.001$ ); in how many of the past seven days did you observe the presence of an ingrown nail $(p=0.001)$.

In a complementary way, Table 3 shows the association between adherence to foot self-care practices and the patients' level of knowledge. The cut-off point established to classify adherence 
Table 2 - Association between the level of knowledge and the weekly practice of foot self-care of patients with diabetes mellitus type 2, Imperatriz, Maranhão, Brazil, 2019

\begin{tabular}{|c|c|c|c|}
\hline \multirow{2}{*}{ Variables } & \multicolumn{2}{|c|}{ Knowledge } & \multirow{2}{*}{$\underset{\text { value* }^{p}}{p}$} \\
\hline & Low & Moderate & \\
\hline In how many of the past seven days did you self-examined your feet & 81.05 & 119.74 & $<0.001$ \\
\hline $\begin{array}{l}\text { In how many of the past seven days have you inspected your shoes before putting } \\
\text { them on }\end{array}$ & 96.25 & 114.32 & 0.079 \\
\hline $\begin{array}{l}\text { In how many of the past seven days have you dried the spaces between your toes } \\
\text { after washing them }\end{array}$ & 90.73 & 134.53 & $<0.001$ \\
\hline In how many of the past seven days have you walked barefoot & 96.72 & 101.75 & 0.479 \\
\hline In how many of the past seven days have you done a foot soak & 98.14 & 94.00 & 0.250 \\
\hline In how many of the past seven days have you used socks to put on closed in shoes & 95.87 & 109.72 & 0.141 \\
\hline $\begin{array}{l}\text { In how many of the past seven days have you moisturized your feet with creams } \\
\text { and oils }\end{array}$ & 94.01 & 116.58 & 0.024 \\
\hline $\begin{array}{l}\text { In how many of the past seven days have you observed the presence of } \\
\text { interdigital mycosis }\end{array}$ & 93.19 & 127.90 & $<0.001$ \\
\hline $\begin{array}{l}\text { In how many of the past seven days have you observed the presence of an } \\
\text { ingrown nail }\end{array}$ & 92.49 & 124.90 & 0.001 \\
\hline
\end{tabular}

Note: *Mann-Whitney test.

Table 3 - Statistic association between the participants' level of knowledge and the adherence of foot self-care practice in patients with diabetes mellitus type 2, Imperatriz, Maranhão, Brazil, 2019

\begin{tabular}{|c|c|c|c|c|c|}
\hline \multirow{2}{*}{ Variables } & \multicolumn{2}{|c|}{ Knowledge } & \multirow{2}{*}{$\begin{array}{l}\text { Total } \\
\text { n (\%) }\end{array}$} & \multirow{2}{*}{$\begin{array}{c}\mathrm{OR}^{*} \\
(95 \% \mathrm{CI})^{\dagger}\end{array}$} & \multirow{2}{*}{$\begin{array}{c}p \\
\text { value* }\end{array}$} \\
\hline & Low & Moderate & & & \\
\hline \multicolumn{6}{|c|}{ Perform foot self-examination } \\
\hline Yes & 40 & 17 & 57 (29.2) & \multirow{2}{*}{$\begin{array}{c}5.64 \\
(2.39-13.32)\end{array}$} & \multirow[t]{2}{*}{$<0.001^{\ddagger}$} \\
\hline No & 125 & 13 & $138(70.8)$ & & \\
\hline \multicolumn{6}{|c|}{ Check inside the shoes before putting them on } \\
\hline Yes & 82 & 19 & $101(51.3)$ & \multirow{2}{*}{$\begin{array}{c}1.79 \\
(0.80-3.99)\end{array}$} & \multirow[t]{2}{*}{$0.151^{\ddagger}$} \\
\hline No & 85 & 11 & $96(48.7)$ & & \\
\hline \multicolumn{6}{|c|}{ Dry interdigital spaces after washing them } \\
\hline Yes & 19 & 6 & $25(26.6)$ & \multirow{2}{*}{$\begin{array}{c}4.04 \\
(1.11-14.72)\end{array}$} & \multirow[t]{2}{*}{$0.036^{\S}$} \\
\hline No & 64 & 5 & $69(73.4)$ & & \\
\hline \multicolumn{6}{|c|}{ Moisturize the feet with creams or oils } \\
\hline Yes & 15 & 3 & $18(19.4)$ & \multirow{2}{*}{$\begin{array}{c}1.67 \\
(0.39-7.07)\end{array}$} & \multirow[t]{2}{*}{$0.360^{\S}$} \\
\hline No & 67 & 8 & $75(80.6)$ & & \\
\hline \multicolumn{6}{|c|}{ Observe the presence of interdigital mycoses } \\
\hline Yes & 12 & 6 & $18(19.2)$ & \multirow{2}{*}{$\begin{array}{c}4.93 \\
(1.30-18.74)\end{array}$} & \multirow[t]{2}{*}{$0.025^{\S}$} \\
\hline No & 71 & 5 & $76(80.8)$ & & \\
\hline \multicolumn{6}{|c|}{ Observe the presence of ingrown nail } \\
\hline Yes & 10 & 6 & $16(17.4)$ & 8.52 & \multirow[t]{2}{*}{$0.003^{\S}$} \\
\hline No & 71 & 5 & $76(82.6)$ & $(2.19-33.16)$ & \\
\hline \multicolumn{6}{|c|}{ Use socks to put on closed in shoes } \\
\hline Yes & 7 & 1 & 08 ( 8.6$)$ & 1.07 & \multirow{2}{*}{$0.650^{\S}$} \\
\hline No & 75 & 10 & $85(91.4)$ & $(0.12-9.64)$ & \\
\hline \multicolumn{6}{|c|}{ Walk barefoot } \\
\hline Yes & 6 & 3 & $9(9.7)$ & 4.75 & \multirow[t]{2}{*}{$0.070^{\S}$} \\
\hline No & 76 & 8 & $84(90.3)$ & $(0.99-22.73)$ & \\
\hline \multicolumn{6}{|c|}{ Footwear that usually uses: } \\
\hline Pointy s & & & & & \\
\hline Yes & 1 & 1 & $2(1.0)$ & 5.86 & $0.277^{\S}$ \\
\hline No & 164 & 28 & $192(99.0)$ & $(0.36-96.38)$ & \\
\hline Open sh & & & & & \\
\hline Yes & 130 & 15 & $145(74.4)$ & 0.27 & $0.001^{\ddagger}$ \\
\hline No & 35 & 15 & $50(25.6)$ & $(0.12-0.60)$ & \\
\hline Tight clc & & & & & \\
\hline Yes & 7 & 1 & $08(4.1)$ & 0.78 & $0.644^{\S}$ \\
\hline No & 158 & 29 & $187(95.9)$ & $(0.09-6.56)$ & \\
\hline Soft and & & & & & \\
\hline Yes & 42 & 16 & $58(29.7)$ & 3.35 & $0.002^{\ddagger}$ \\
\hline No & 123 & 14 & $137(70.3)$ & $(1.51-7.44)$ & \\
\hline
\end{tabular}

as positive was five days. The results found indicated that patients with moderate knowledge were eight times more likely to observe the presence of ingrown toenails (RC: $8.52 ; p=0.003$ ); five times more likely to perform foot self-examination (RC: 5.64 ; p $=<0,001$ ); approximately five times more likely to observe the presence of interdigital mycoses (RC: 4.93; $p=0.025$ ); four times more likely to dry the interdigital spaces (RC: 4.04; $p=0.036$ ); four times more likely to not walking barefoot (RC: 4.75; $\mathrm{p}=0.036$ ); and three times more likely to use soft closed in shoes (RC: 3.35; $p=0.002$ ).

\section{DISCUSSION}

When analyzing the characterization of the sample of this study, we observed a predominance of female patients, which corroborates other research carried out with patients affected by diabetes mellitus ${ }^{(16-17)}$. The fact that can justify these data is that women seek health services more than men, either because they are more available than them or because they present a more holistic view of the care they should take with health ${ }^{(18)}$. The fact that male patients seek health services less often means that they have little contact with professionals who carry out health promotion and prevention activities, and this influences the level of knowledge they have about diabetes and necessary self-care practices. To prevent complications such as diabetic foot ${ }^{(19)}$. As a result, studies have found that the association between the variables "low level of knowledge" and "male gender" is a risk factor for non-traumatic amputations $^{(20-21)}$. 
Regarding the level of education, most of the participants had a low level of study, which can make it challenging to understand the guidelines provided by the health team and, consequently, make them more susceptible to not performing self-care practices ${ }^{(4)}$. Low schooling has been identified as an important risk factor for the development of diabetes complications because it is related to insufficient knowledge. This low level can influence the patients' ability to understand the importance of carrying out practices related to lifestyle changes, necessary for the control of diabetes, and foot self-care to prevent ulcerations ${ }^{(22)}$.

The literature also highlights that old age and low income are factors that can contribute to a lesser understanding of the information received and the impact that exposure to risk factors can generate over time. In this sense, it is known that socioeconomic factors interfere with life habits and self-care practices - such as the acquisition of products for a healthy life and, also, adherence to the guidelines indicated for the control of the disease $\mathrm{e}^{(23)}$. In contrast, a variable that can positively contribute to adherence to self-care practices consists of marital status. About this, a study showed that having a spouse collaborates for a greater willingness to carry out self-care activities for health maintenance ${ }^{(24)}$. The present investigation observed that most of the sample consisted of older adults, married and with family income less than or equal to a minimum wage.

The data obtained in this study pointed out that, in general, patients with a higher level of knowledge had greater adherence to foot care, with emphasis on daily self-examination, hydration of the feet, interdigital drying, and observation of the presence of mycosis and ingrown nails. Another study, which assessed patients' knowledge after an educational activity, found that those classified as having adequate knowledge started to check their feet daily, walk with shoes, do not do foot soak, hydrate, and cut their nails properly ${ }^{(25)}$. Also, a study carried out in the rural area of a municipality in southern Brazil found that low education directly interfered with the knowledge of diabetic patients to develop foot self-care practice ${ }^{(26)}$.

The practices of daily foot care actions can prevent the occurrence of injuries and infections in the lower limbs, so it is essential that health professionals, especially nurses, guide the care that should be practiced ${ }^{(21)}$. Among these precautions, the habit of drying the interdigital spaces stands out, as it reduces the risk of infections, which are one of the main causes of lower limb amputations ${ }^{(27)}$.

In addition to adequate knowledge, other factors can also interfere with adherence to self-care practices, such as gender. Research on knowledge of preventive measures about the diabetic foot observed this fact, in which men stated that they did not hydrate their feet for cultural reasons and for attributing this practice to the female gender ${ }^{(28)}$. This practice avoids the dryness of the skin and the appearance of fissures, which are gateways to the occurrence of infectious processes and the appearance of tissue lesions ${ }^{(21)}$.

This study observed the relationship between knowledge and the implementation of foot self-care practice since patients with moderate knowledge were more likely to adhere to the habit of observing the presence of ingrown toenails (onychoptosis). This fact is considered necessary for the prevention of damage and health problems, since the injuries resulting from onychoptosis act as a gateway for secondary bacterial infection, in addition to contributing to the onset of ulcers ${ }^{(29)}$. Furthermore, interdigital mycosis also consists of one of the factors that may be associated with the occurrence of infections, as identified in a case-control study carried out with diabetic and non-diabetic patients, which found a higher prevalence of mycosis in the nails and the interdigital spaces between the people with diabetes ${ }^{(30)}$. Interdigital mycoses are the gateway to infections, as well as injuries resulting from trauma and the use of inappropriate shoes and are related to higher rates of amputations ${ }^{(26)}$.

Concerning the use of footwear, diabetic patients evaluated in this study who had moderate knowledge were more likely to use appropriate footwear when compared to those who had insufficient knowledge. Most people with diabetes are unaware that the ideal shoes for use are closed and comfortable. A study that evaluated the guidelines and knowledge about preventive care performed by diabetic individuals observed this fact since most of the sample evaluated used open shoes like sandals ${ }^{(28)}$.

A survey carried out in Maringá observed this since almost all diabetics interviewed (77 patients) were unaware of the ideal characteristics for their shoes, prioritizing the only comfort when purchasing them. The use of suitable footwear is of great importance for injury prevention because it protects the feet against trauma and abrasions. However, they must not have seams, they must not be wide or tight, as this type of footwear provides the appearance of bubbles due to friction ${ }^{(7)}$.

As for the habit of walking barefoot, the present study showed that patients with greater knowledge walk barefoot less frequently, which is a positive factor since the use of footwear protects the feet from external harmful agents; thus, it is considered a preventive measure. About this, the literature highlights that the habit of walking barefoot is harmful, especially when the patient with DM has some type of deformity or loss of protective sensitivity ${ }^{(31)}$.

Given the above, we perceive the importance of diabetic patients having adequate knowledge about foot physical examination in order to perform the recommended self-care practices satisfactorily. This knowledge can be acquired or improved through guidelines provided by nurses, as education and health promotion are considered essential for the prevention of diseases, especially for patients with chronic diseases ${ }^{(32)}$. Therefore, the nurse must act in the training of the individual, family, and community to understand the risk of ulceration and the impact caused by foot changes. It is also noteworthy that these actions must be dynamic, with accessible information and language, which include the execution of foot self-examination and their adherence to prevent infections $s^{(9)}$.

\section{Study limitations}

The fact that the study presents a cross-sectional design does not allow us to conclude what is the nature of the relationship between exposure and event. The geographical delimitation can be considered a limitation since the education levels of the population may vary according to the region of the country, which can restrict the ability to generalize the results. Besides, issues 
related to socio-cultural behaviors, which can influence self-care and illness, were not the object of this study and, therefore, were not evaluated.

\section{Contributions to the nursing field}

The results found show a close relationship between the patient's knowledge and adherence to foot care, expressing the dimension of the importance of effective nursing performance in training the individual for self-care. It also allows the reflection that care goes beyond the clinical understanding of the disease and that nursing studies must continue beyond the physiological understanding of the illness. This knowledge of nursing must converge to identify the challenges experienced by the assisted population since such situations corroborate or not the success of the therapeutic plan. In this way, the results of the present study may guide nursing professionals in establishing health practices for diabetic patients that help foot care practice.

\section{CONCLUSIONS}

The patients with the highest level of knowledge were the ones most likely to adhere to self-care practices, such as performing foot self-examination, using the correct type of shoes, drying the interdigital spaces of the feet after washing them, observing the presence of interdigital mycosis, moisturizing the feet with creams and oils and observing the presence of ingrown toenails. Therefore, knowledge becomes a basis for the practices of daily self-care and prevention of foot changes, especially for people with diabetes. This information can support health education actions aimed at training the patients, as it allows them to clarify their doubts and work on their skills, achieving effectiveness in daily self-care.

\section{REFERENCES}

1. American Diabetes Association. Standards of medical care in diabetes-2015. Diabetes Care [Internet]. 2015 [cited 2019 Mar 25];38(S1):S1-S93. Available from: http://care.diabetesjournals.org/content/suppl/2014/12/23/38.Supplement_1.DC1/January_ Supplement_Combined_Final.6-99.pdf

2. Targino IG, Souza JSO, Santos NMG, Davim RMB, Silva RAR. Factors related to the development of ulcers in patients with Diabetes Mellitus. Rev Pesqui Cuid Fundam. 2016;8(4):4929-34. doi: 10.9789/2175-5361.2016.v8i4.4929-4934

3. Maffacciolli R, Oliveira DLLC. Challenges and perspectives of nursing care to vulnerable populations. Rev Gaúcha Enferm. 2018;39:e20170189. doi: 10.1590/1983-1447.2018.20170189

4. Morey-Vargas OL, Smith SA. Be Smart: strategies for foot care and prevention of foot complications in patients with diabetes. Prosthet Orthot Int. 2015;39(1):48-60. doi: 10.1177/0309364614535622

5. Galdino YLS, Moreira TMM, Marques ADB, Silva FAA. Validation of a booklet on self-care with the diabetic foot. Rev Bras Enferm. 2019;72(3):780-7. doi: 10.1590/0034-7167-2017-0900

6. Ortiz LMO, Damião EBC, Rossato LM, Alves RCP. Best nursing practices in diabetes education for the hospitalized child: an integrative review. Rev Eletrôn Enferm. 2017;19:a56. doi: 10.5216/ree.v19.45655

7. Carlesso GP, Gonçalves MHB, Moreschi Jr D. Evaluation of diabetic patients knowledge about preventive care of the diabetic foot, in Maringá, PR, Brazil. J Vasc Bras. 2017;16(2):113-8. doi: 10.1590/1677-5449.006416

8. Nascimento TCO, Navarine TCRR, Anízio BKF, Anízio BF, Costa MML, Santos IBC. Knowledge of patients with diabetes mellitus about lesions on the limbs. Rev Enferm UFPE. 2014;8(7):1888-97. doi: 10.5205/1981-8963-v8i7a9863p1888-1897-2014

9. Ramirez-Perdomo C, Perdomo-Romero A, Rodríguez-Vélez M. Knowledge and practices for the prevention of the diabetic foot. Rev Gaúcha Enferm. 2019;40:e20180161. doi: 10.1590/1983-1447.2019.20180161

10. Menezes LCG, Guedes MVC, Moura NS, Moura DJM, Vieira LA, Barros AA. Conhecimento do Enfermeiro da Atenção Primária à Saúde Sobre os Cuidados com o Pé Diabético. Estima. 2017;15(2):100-6. doi: 10.5327/Z1806-3144201700020006

11. Flora MC, Gameiro MGH. Autocuidado dos Adolescentes com Diabetes Mellitus Tipo 1: Conhecimento acerca da Doença. Rev Enf Ref. 2016;4(8):17-26. doi: 10.12707/RIV15024

12. Teston E, Souza Senteio J, Ribeiro BMDSS, Maran E, Marcon SS. Risk factors for foot ulceration in individuals with type 2 diabetes mellitus. Cogitare Enferm [Internet]. 2017 [cited 2019 Oct 15];22(4). Available from: https://www.redalyc.org/service/redalyc/ downloadPdf/4836/483654880019/8.

13. Michels MJ, Coral MHC, Sakae TM, Damas TB, Furlanetto LM. Questionário de Atividades de Autocuidado com o Diabetes: tradução, adaptação e avaliação das propriedades psicométricas. Arq Bras Endocrinol Metab. 2010;54(7):644-51. doi: 10.1590/ S0004-27302010000700009

14. Sociedade Brasileira de Diabetes. Diretrizes da Sociedade Brasileira de Diabetes (2017-2018) [Internet]. 2017 [cited 2019 Oct 15]. Available from: https://www.diabetes.org.br/profissionais/images/2017/diretrizes/diretrizes-sbd-2017-2018.pdf

15. Neta R, Sá D, Silva ARVD, Silva GRFD. Adherence to foot self-care in diabetes mellitus patients. Rev Bras Enferm. 2015;68(1):111-6. doi: 10.1590/0034-7167.2015680115p

16. Moreschi C, Rempel C, Siqueira DF, Backes DS, Pissaia LF, Grave MTQ.Family Health Strategies: Profile/quality of life of people with diabetes. Rev Bras Enferm. 2018;71(6):2899-906. doi: 10.1590/0034-7167-2018-0037 
17. Assunção SC, Fonseca AP, Silveira MF, Caldeira AP, Pinho L. Knowledge and attitude of patients with diabetes mellitus in Primary Health Care. Esc Anna Nery. 2017;21(4). doi: 10.1590/2177-9465-ean-2017-0208

18. Oliveira Neto M, Pereira MS, Pinto MAH, Agostinho LM, Reinaldo Jr FE, Hissa MN. Avaliação do autocuidado para a prevenção do pé diabético e exame clínico dos pés em um centro de referência em diabetes mellitus. J Health Biol Sci. 2017;5(3):265-71. doi: 10.12662/23173076jhbs.v5i3.1092.p265-271.2017

19. Rossaneis MA, Haddad MCFL, Mathias TAF, Marcon SS. Differences in foot self-care and lifestyle between men and women with diabetes mellitus. Rev Latino-Am Enferm. 2016;24:e2761. doi: 10.1590/1518-8345.1203.2761

20. Laclé A, Valero-Juan LF. Diabetes-related lower extremity amputation incidence and risk factors: a prospective seven-year study in Costa Rica. Rev Panam Salud Publica [Internet]. 2012 [cited 2019 May 25];32(3):192-8. Available from: https://www.scielosp.org/pdf/rpsp/2012.v32n3/192-198/en

21. Silva PL, Rezende MP, Ferreira LA, Dias FA, Silveira FCO. Cuidados com os pés: o conhecimento de indivíduos com diabetes mellitus cadastrados no programa saúde da família. Enferm Glob [Internet]. 2015 [cited 2019 May 20];14(1):38-51. Available from: https://revistas. um.es/eglobal/article/view/eglobal.14.1.170401/168631

22. Borba AKDOT, Arruda IKG, Marques APDO, Leal MC, Diniz ADS. Knowledge and attitude about diabetes self-care of older adults in primary health care. Ciênc Saúde Colet. 2019;24(1):125-36. doi: 10.1590/1413-81232018241.35052016

23. Peykari N, Djalalinia S, Kasaeian A, Naderimagham S, Hasannia T, Larijani B, et al. Diabetes research in Middle East countries; a scientometrics study from 1990 to 2012. J Res Med Sci [Internet]. 2015 [cited 2019 Oct 22];20(3):253. Available from: https://www.ncbi.nlm.nih.gov/pmc/ articles/PMC4468230/

24. August KJ, Rook KS, Franks MM, Parris Stephens MA. Spouses' involvement in their partners' diabetes management: Associations with spouse stress and perceived marital quality. J Fam Psychol [Internet]. 2013 [cited 2019 Oct 23];27(5):712. Available from: https://psycnet.apa.org/ record/2013-32705-001

25. Martin VT, Rodrigues CDS, Cesarino CB. Conhecimento do paciente com Diabetes Mellitus sobre o cuidado com os pés. Rev Enferm UERJ [Internet]. 2011 [cited 2019 May 15];19(4):621-5. Available from: http://www.facenf.uerj.br/v19n4/v19n4a20.pdf

26. Silva JMTS, Haddad MCFL, Rossaneis MA, Vannuchi MTO, Marcon SS. Factors associated with foot ulceration of people with diabetes mellitus living in rural areas. Rev Gaúcha Enferm. 2017;38(3):e68767. doi: 10.1590/1983-1447.2017.03.68767

27. Cubas MR, Santos OM, Retzlaff EMA, Telma HLC, Andrade IPS, Moser ADL, et al. Pé diabético: orientações e conhecimento sobre cuidados preventivos. Fisioter Mov. 2017;26(3):647-55. doi: 10.1590/S0103-51502013000300019

28. Policarpo NS, Moura JRA, Melo Jr EB, Almeida PC, Macêdo SF, Silva ARV. Knowledge, attitudes and practices for the prevention of diabetic foot. Rev Gaúcha Enferm. 2014;35(3):36-42. doi: 10.1590/1983-1447.2014.03.45187

29. Cardoso VS, Magalhães AT, Silva BAK, Silva CS, Gomes DBC, Silva JCA. Functional assessment of feet of patients with type II diabetes. Rev Bras Promoç Saúde. 2013;26(4):563-70. doi: 10.5020/18061230.2013.p563

30. Papini M, Cicoletti M, Fabrizi V, Landucci P. Skin and nail mycoses in patients with diabetic foot. G Ital Dermatol Venereol [Internet]. 2013 [cited 2019 May 25];148(6):603-8. Available from: https://www.researchgate.net/profile/Manuela_Papini2/publication/259808198_Skin_ and_nail_mycoses_in_patients_with_diabetic_foot/links/0deec5304f6732ef85000000.pdf

31. Rodriguez MCP, Godoy S, Mazzo A, Nogueira PC, Trevizan MA, Mendes IAC. Cuidado com os pés diabéticos antes e após intervenção educativa. Enferm Glob [Internet]. 2013 [cited 2019 May 20];29: 53-62. Available from: http://scielo.isciii.es/pdf/eg/v12n29/pt_clinica3.pdf

32. Gonçalves FG, Albuquerque DC. Educação em saúde de pacientes portadores de insuficiência cardíaca. Rev Enferm UERJ [Internet]. 2014 [cited 2019 May 20]; 22(3):422-8. Available from: https://www.e-publicacoes.uerj.br/index.php/enfermagemuerj/article/view/13769/10514 